\title{
Use of CALPUFF and CAMx models in regional air quality planning: Italy case studies
}

\author{
C. Trozzi, S. Villa \& E. Piscitello \\ Techne Consulting srl, Rome, Italy
}

\begin{abstract}
Applications of air pollution dispersion models CALPUFF and CAMx have been performed over regional Italy territories in order to evaluate transport, wet and dry deposition of coarse and fine particulates and formation of secondary fine particulates with special attention to nitrates and sulphates.

Two different geographical domains were chosen, Trento and Florence provinces, with horizontal cells the size of $1 \mathrm{~km} \times 1 \mathrm{~km}$, and meteorological variables were considered from meteorological models and local measurements as well; emissions were taken from high resolution bottom-up emission inventories and the time scale was spanning an entire year on hourly basis.

Results show how the more accurate chemical model contained in CAMx performs better in secondary particulates formation, in particular regarding the sulphates, while CALPUFF seems slighlty better in predicting dispersion paths. Even if both models application suffers from lack of background concentrations of particulate matter, the CALPUFF model produces more accurate hourly concentration values in the single cell, making this model a better choice between the two in total PM evaluation for this particular case study. Correlation between CAMx and CALPUFF predicted data is also strong.
\end{abstract}

\section{Introduction}

The best dispersion model choice in a regional air pollution study is often a very debated topic, since every model has his strong and weak spots over a wide variety of characteristics needed by this kind of study.

We choose to compare Calpuff [1] and CAMx [2] models over two very different geographic domains in terms of geomorphology: the Trento province 
presents a typical alpine or subalpine scenario, with a lot of canyons and high peaks, thus most of human activities, and so pollution, carried out in valleys; the Florence province, on the other hand, presents wider flat territories, gentle hills and sub mountainous terrain only in the northeastern corner, thus with a more spread pollution production in terms of geography.

\section{Characteristics of simulations}

For both studies and both models, we used a $1 \mathrm{Km}$ wide cells grid covering the entire province, surface weather data from regional weather stations networks, upper air data from application of MM5 [3] and CALMET [4] weather forecast models and emission data from high resolution bottom-up managed by APEX system [5] over a time period of several years. Spatial and temporal subdivision of emissions data was the same for both models and was carried out by appropriate preprocessors [5]. Both models were run over a time period of a year on an hourly basis.

\section{Models calibration}

Calibration of models were performed over three different kinds of sampling stations; we choose an urban traffic, an urban background and a rural background sampling station for every province; in this way we can see how models perform on those kinds of territories, the results (in monthly mean for January, but results are similar for every month) show clearly (Table 1) a lack of background particulates concentration that could be filled e.g. with accounting of transboundary particulates fluxes from a continental scale model [6].

Since we did not have hourly data of background particulates, the statistical indexes like fractional bias and normalized gross error, calculated on hourly basis, are not shown for $\mathrm{PM}_{10}$. Statistical indexes are calculated for every model in respect to measured data from sampling stations.

In Table 2 computed statistical indexes [7] are reported for selected pollutants and networks. Calibration results show that CAMx model in Florence province performs better than CALPUFF as long as we move from traffic to rural station. This behaviour is opposite in Trento province, especially in terms of fractional bias. This kind of behaviour can be ascribed to the different nature of the models, the lagrangian CALPUFF seems to better reconstruct paths of pollutants in canyons and to overestimate concentrations in urban zones in some cases.

\section{Results for particulates}

Both models can treat secondary particulate formation and transport, though CALPUFF chemical internal module MESOPUFF II is less complex than CBIV 
Table 1: Calibration of models: comparison of measured and computed average concentrations $\left(\mu \mathrm{g} / \mathrm{m}^{3}\right)$ for selected sampling station.

\begin{tabular}{|c|c|c|c|c|}
\hline Province & Station & Measure & $\begin{array}{c}\mathrm{NO}_{2} \\
\text { Calpuff }\end{array}$ & CAMx \\
\hline \multirow{3}{*}{ Florence } & Urban traffic & 101.85 & 72.25 & 42.94 \\
\hline & Urban background & 42.50 & 65.17 & 35.58 \\
\hline & Rural background & 19.41 & 32.29 & 18.92 \\
\hline \multirow{4}{*}{ Trento } & Urban traffic & 58.47 & 28.23 & 28.18 \\
\hline & Urban background & 51.79 & 29.40 & 17.95 \\
\hline & Rural background & 2.23 & 2.62 & 5.54 \\
\hline & & & $\mathrm{SO}_{2}$ & \\
\hline \multirow{3}{*}{ Florence } & Urban traffic & 4.88 & 6.92 & 4.76 \\
\hline & Urban background & 3.48 & 5.02 & 2.53 \\
\hline & Rural background & N/A & 2.56 & 1.00 \\
\hline \multirow{4}{*}{ Trento } & Urban traffic & 5.65 & 4.77 & 6.97 \\
\hline & Urban background & N/A & 4.34 & 3.54 \\
\hline & Rural background & N/A & 0.67 & 0.96 \\
\hline & & & $\mathrm{PM}_{10}$ & \\
\hline \multirow{3}{*}{ Florence } & Urban traffic & 42.53 & 12.09 & 6.64 \\
\hline & Urban background & 29.43 & 10.73 & 4.47 \\
\hline & Rural background & N/A & 6.96 & 2.16 \\
\hline \multirow{3}{*}{ Trento } & Urban traffic & 34.31 & 4.99 & 2.84 \\
\hline & Urban background & 44.45 & 4.36 & 1.69 \\
\hline & Rural background & $\mathrm{N} / \mathrm{A}$ & 0.88 & 0.32 \\
\hline
\end{tabular}

chemical model contained in CAMx. The former has only capabilities to produce $\mathrm{SO}_{4}$ and $\mathrm{NO}_{3}$ aggregates while the latter can treat in addition organic aerosol and elemental carbon as well.

The following graphs will show comparison between the two models in terms of hourly concentrations calculated over the urban traffic stations (Figures 1 and 2), urban background stations (Figures 3 and 4), rural station (Figures 5 and 6) respectively for $\mathrm{PM}_{10}$ and secondary particulates expressed as sum of all subspecies produced and treated by the models.

Correlation between the two hourly series produced by the models for every kind of cell is shown in Table 3.

From these results, it is clear that, given the same methodology in terms of meteorology and emissions, the two models perform very different when two geographical domains are of so different nature. While correlation decreases in both cases as long as we move from traffic to rural stations, that quantity shows poor values, below $60 \%$, for Trento province. In addition, concentrations of particulates given by CALPUFF are always higher than those from CAMx in terms of monthly means; thus, regardless of available background concentrations of particulates, the CALPUFF model shows the best performance in total PM determination. 
Table 2: Calibration of models: Statistical indexes in selected sampling station.

\begin{tabular}{|c|c|c|c|c|c|}
\hline \multirow{3}{*}{ Province } & \multirow{3}{*}{ Station } & \multirow{2}{*}{\multicolumn{2}{|c|}{$\begin{array}{c}\text { Fractional Bias } \\
\mathrm{NO}_{2}\end{array}$}} & \multirow{2}{*}{\multicolumn{2}{|c|}{$\frac{\text { Normalized gross error }}{\mathrm{NO}_{2}}$}} \\
\hline & & & & & \\
\hline & & CALPUFF & CAMx & CALPUFF & CAMx \\
\hline \multirow[t]{3}{*}{ Florence } & Urban traffic & -0.34 & -0.81 & 0.70 & 0.59 \\
\hline & Urban background & 0.42 & -0.18 & 1.14 & 0.46 \\
\hline & Rural background & 0.50 & -0.03 & 1.35 & 0.71 \\
\hline \multirow[t]{4}{*}{ Trento } & Urban traffic & -0.70 & -0.70 & 0.62 & 0.58 \\
\hline & Urban background & -0.55 & -0.97 & 0.64 & 0.75 \\
\hline & Rural background & 0.16 & 0.85 & 1.35 & 1.65 \\
\hline & & \multicolumn{2}{|c|}{$\mathrm{SO}_{2}$} & \multicolumn{2}{|c|}{$\mathrm{SO}_{2}$} \\
\hline \multirow[t]{3}{*}{ Florence } & Urban traffic & 0.35 & -0.02 & 1.11 & 0.77 \\
\hline & Urban background & 0.36 & -0.32 & 1.39 & 0.84 \\
\hline & Rural background & N/A & N/A & N/A & N/A \\
\hline \multirow[t]{3}{*}{ Trento } & Urban traffic & -0.17 & 0.21 & 0.72 & 0.83 \\
\hline & Urban background & N/A & N/A & N/A & N/A \\
\hline & Rural background & N/A & N/A & N/A & N/A \\
\hline
\end{tabular}
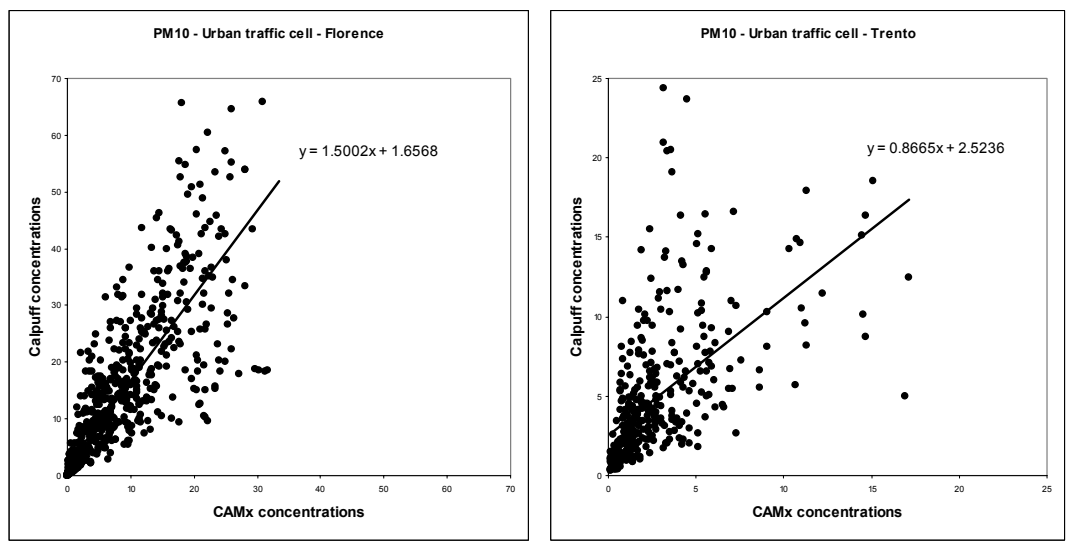

Figure 1: Models comparison: hourly $\mathrm{PM}_{10}$ concentrations - urban traffic cell. 

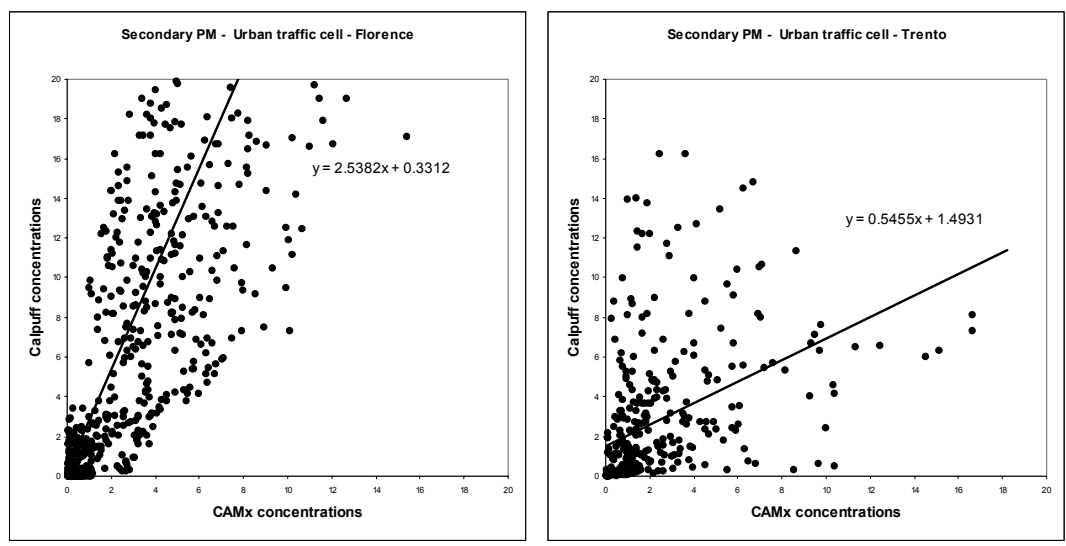

Figure 2: Models comparison: hourly secondary particulates concentrations urban traffic cell.
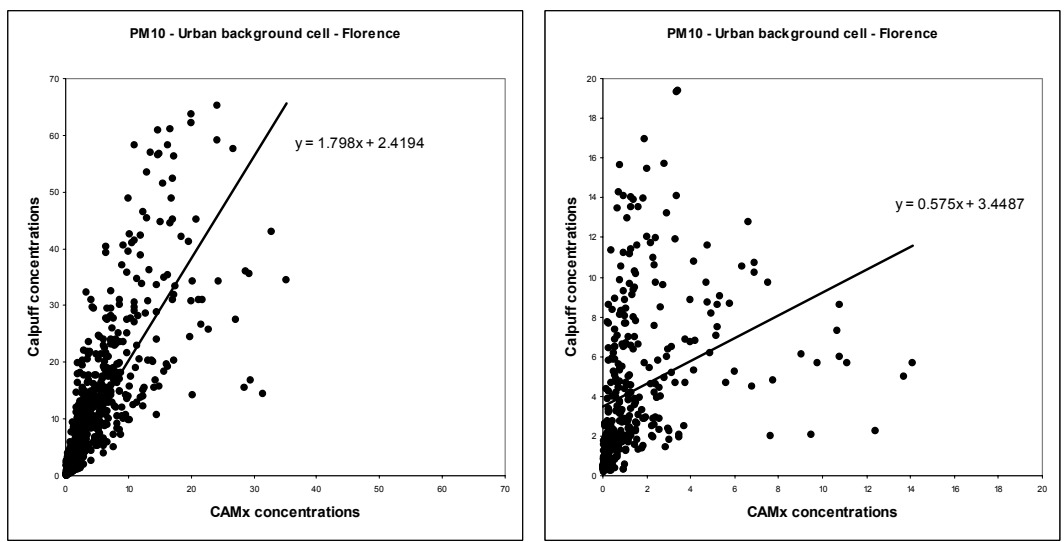

Figure 3: Models comparison: hourly $\mathrm{PM}_{10}$ concentrations - urban background cell. 

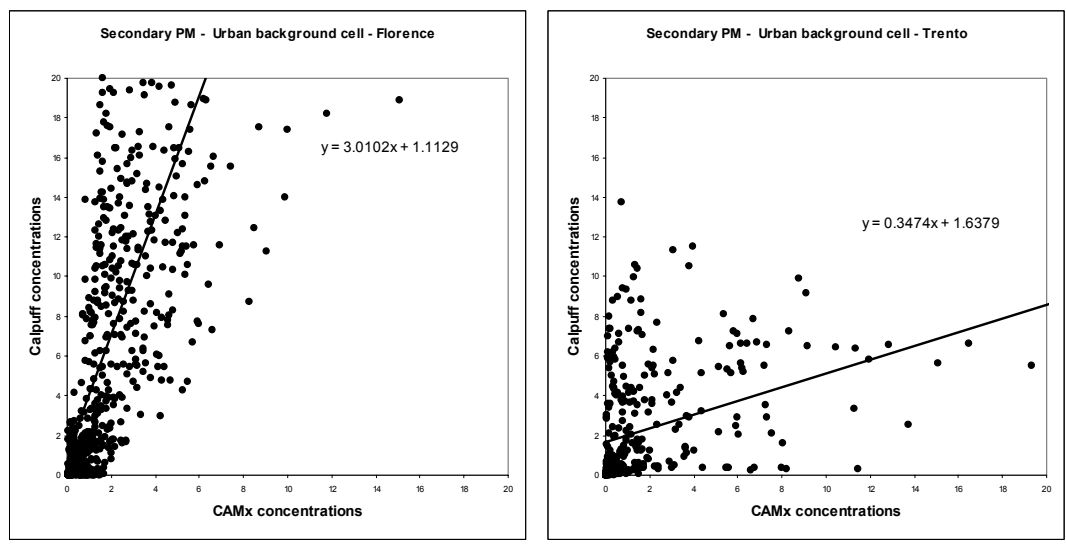

Figure 4: Models comparison: hourly secondary particulates concentrations urban background cell.
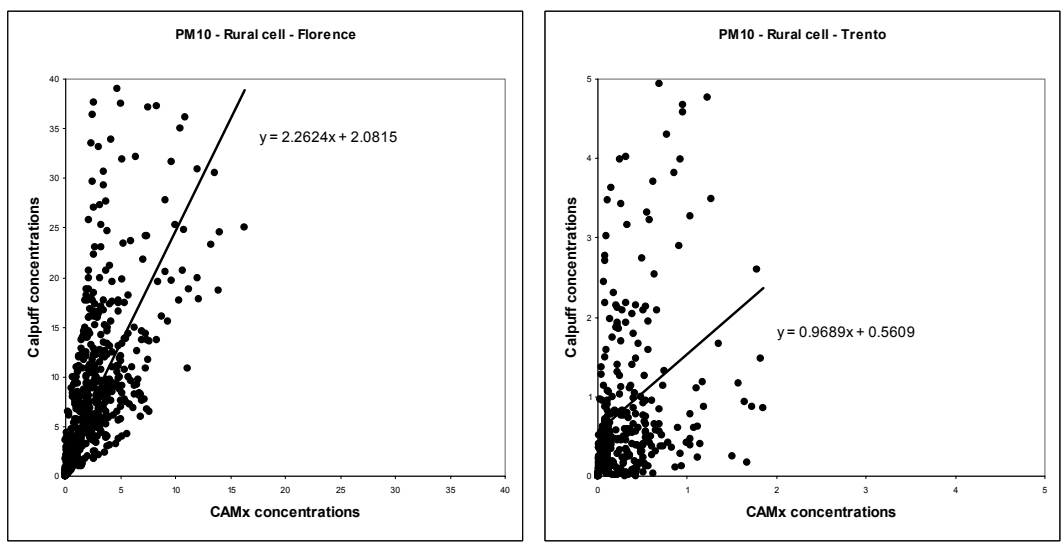

Figure 5: Models comparison: hourly $\mathrm{PM}_{10}$ concentrations - rural cell. 

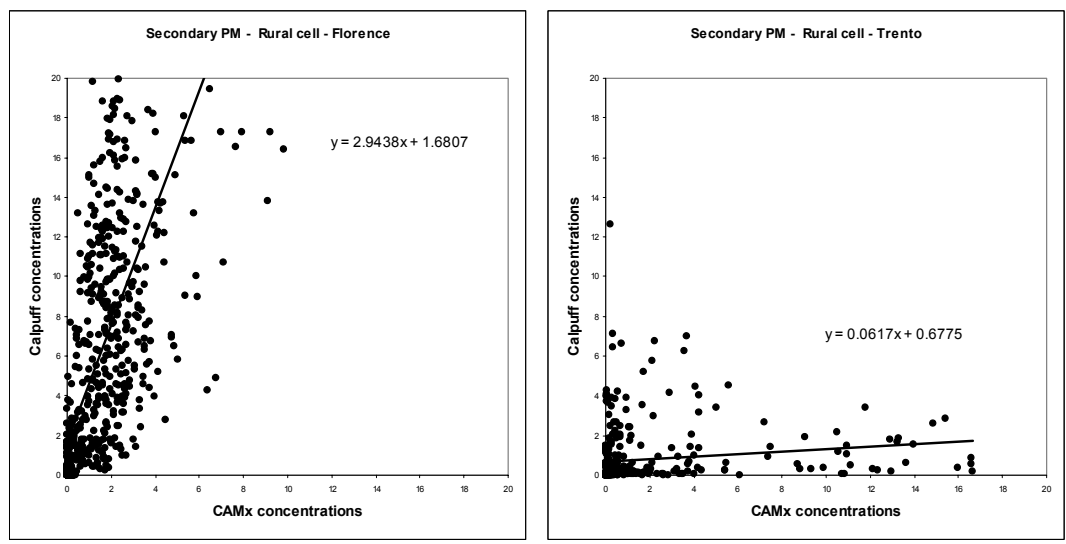

Figure 6: Models comparison: hourly secondary particulates concentrations rural cell.

Table 3: Models comparison: correlation of hourly $\mathrm{PM}_{10}$ and secondary particulates concentrations.

\begin{tabular}{llcc}
\hline & & $\mathrm{PM}_{10}$ & Sec. PM \\
\hline \multirow{4}{*}{ Florence } & Urban traffic & 0.83 & 0.78 \\
& Urban background & 0.78 & 0.73 \\
& Rural background & 0.71 & 0.64 \\
\multirow{7}{*}{ Trento } & Urban traffic & 0.57 & 0.43 \\
& Urban background & 0.33 & 0.39 \\
& Rural background & 0.27 & 0.14 \\
\hline
\end{tabular}

\subsection{Nitrates and sulphates percentages in secondary PM}

Trento province presented a higher share of sulphur dioxides emissions than Florence province; this resulted in a different composition of secondary PM for both CALPUFF and CAMx models, that showed higher percentages of sulphates for Trento province as listed in Table 4.

From Table 5, it is clear that CAMx model responds better to emission variation of sulphur dioxide, changing the percentages of sulphates in secondary PM accordingly; where CAMx shows even a variation in percentage of 63 points, like the case of rural stations, CALPUFF only vary a little.

CAMx seems on the other hand to underestimate nitrates, but since we didn't have measured data for secondary PM, it's hard to say what model is nearest to the real values. Surely the most complex chemical mechanism of CAMx can assure a wider variety of chemical species involved and so the possibility to go deeper in determination of secondary particulates formation and transport. 
Table 4: Composition of secondary PM.

\begin{tabular}{|c|c|c|c|c|}
\hline & & Urban Traffic & Urban Background & Rural Background \\
\hline & & \multicolumn{3}{|c|}{ CAMx } \\
\hline \multirow[t]{4}{*}{ Florence } & PEC & $11.89 \%$ & $11.80 \%$ & $12.63 \%$ \\
\hline & $\mathrm{PNO}_{3}$ & $2.07 \%$ & $1.76 \%$ & $2.47 \%$ \\
\hline & POA & $62.69 \%$ & $63.91 \%$ & $58.67 \%$ \\
\hline & $\mathrm{PSO}_{4}$ & $23.35 \%$ & $22.54 \%$ & $26.22 \%$ \\
\hline \multirow[t]{5}{*}{ Trento } & PEC & $6.93 \%$ & $4.29 \%$ & $1.46 \%$ \\
\hline & $\mathrm{PNO}_{3}$ & $0.26 \%$ & $0.14 \%$ & $0.15 \%$ \\
\hline & POA & $38.05 \%$ & $23.42 \%$ & $8.45 \%$ \\
\hline & $\mathrm{PSO}_{4}$ & $54.76 \%$ & $72.14 \%$ & $89.94 \%$ \\
\hline & & \multicolumn{3}{|c|}{ CALPUFF } \\
\hline \multirow[t]{4}{*}{ Florence } & PEC & N/A & N/A & N/A \\
\hline & $\mathrm{PNO}_{3}$ & $62.12 \%$ & $62.12 \%$ & $59.00 \%$ \\
\hline & POA & N/A & N/A & N/A \\
\hline & $\mathrm{PSO}_{4}$ & $37.88 \%$ & $37.88 \%$ & $41.00 \%$ \\
\hline \multirow[t]{4}{*}{ Trento } & PEC & N/A & N/A & N/A \\
\hline & $\mathrm{PNO}_{3}$ & $55.64 \%$ & $50.31 \%$ & $51.50 \%$ \\
\hline & POA & N/A & N/A & N/A \\
\hline & $\mathrm{PSO}_{4}$ & $44.36 \%$ & $49.69 \%$ & $49.50 \%$ \\
\hline
\end{tabular}

PEC: Elemental Carbon Aerosol, PNO3: Nitrates Aerosol, POA: Organic Aerosol, PSO4: Sulphates Aerosol.

\section{Conclusions}

Comparison of the two models not only shows natural differences in pollutants concentrations due to the different approach in physics or chemical modelling, but even due to the kind of geographical domain of application. While a domain mainly composed by plains or gentle hills, like the Florence domain, keeps acceptable values of correlation between CALPUFF and CAMx calculated concentrations, a mountainous domain, with peaks and deep valleys like the Trento's one, does not.

In addition, while correlation decreases in both cases as long as we move from urban to rural cells, analysis of monthly means and statistical indexes shows that CAMx model in Florence province performs better than CALPUFF as long as we move from traffic to rural station. This behaviour is opposite in Trento province, especially in terms of fractional bias.

CAMx model responds better to variation in sulphur emissions in secondary sulphate particulates formation and transport, though the lack of measured data does not allow one to say more in that sense.

Further application of both models on very different geographical domains, accounting of background particles from a continental scale model, and sampling station network capable of measuring secondary particulates will surely contribute to go deeper in this kind of study, especially for particulates. 


\section{References}

[1] Scire J.S., Yamartino R.J., Strimaitis D.G.: A user's guide for the CALPUFF dispersion model, TRC Companies

[2] Yarwood G. et al.: CAMx user's guide ver. 4.3, Environ Corporation

[3] Dudhia J., Gill D., Manning K.: PSU/NCAR Mesoscale Modeling System Tutorial Class Notes and User's Guide MM5 Modeling System Version 3

[4] Scire J.S., Insley E.M., Yamartino R.J., and Fernau M.E.: A User's Guide for the CALMET Meteorological Model, TRC Companies

[5] C. Trozzi, E. Piscitello, S. Giammarino, R. Vaccaro, Advanced Pollutant Emissions Computer System (APEX 4.0), $9^{\text {th }}$ Int. Conf. Model. Monit. Manag. Envir. Probl. - Envirosoft 2002 - 6-8, May 2002 - Bergen (N), Organized by WIT

[6] EMEP Co-operative Programme for Monitoring and Evaluation of the Long-Range Transmission of Air Pollutants in Europe, Transboundary particulate matter in Europe, Status report 2006, Joint, CCC \& MSC-W, Report 2006

[7] Zannetti P. Air pollution modeling. Theories, Computational Methods and Available Software Computational Mechanics Publ.: Southampton \& Boston, 1990

[8] Koo, B., A.S. Ansari, and S.N. Pandis. 2003. Integrated Approaches to Modeling the Organic and Inorganic Atmospheric Aerosol Components. Atmos. Environ., 37, 4757-4768 